\title{
APPRECIATION OF THE SWISS FRANC AND ITS IMPACT ON ROMANIA AND OTHER CENTRAL AND EASTERN EUROPEAN COUNTRIES
}

\author{
David Delia, PhD \\ "Vasile Goldis" Western University of Arad, Romania \\ david_delia2003@yahoo.com \\ Rai Shailendra Kumar, PhD \\ Management Development Institute, Gurgaon, India \\ shailendrakrai@gmail.com \\ Paiusan Luminita, PhD \\ "Vasile Goldis" Western University of Arad, Romania \\ paiusan_luminita@yahoo.com
}

(Received July 2015; accepted September 2015)

\begin{abstract}
The decision of the Swiss National Bank of giving up the fixed rate of 1,2 Euro/CHF on the $15^{\text {th }}$ of January 2015, a rate established at its admission to the Monetary Economic Union, had consequences on Central and Eastern European countries because a great part of the credits granted were in Swiss francs. In all these countries, the national currencies depreciated and the financial market rates were reduced. Regional banks started to face difficulties regarding the management of the situation and were under the necessity of finding solutions to avoid the risk of not recovering the granted credits. The issue of the Swiss franc appreciation was treated differently by the analysed countries and took into consideration the particularities characteristic to the credits granted in this currency. The present paper aims at emphasising the impact of the Swiss franc appreciation on the Romanian banking system but also the approach of other countries in Central and Eastern Europe in this respect.
\end{abstract}

Key words: Swiss franc appreciation, Swiss National Bank, Swiss franc credits, financial stability

J.E.L. CODES: G1; G2

\section{Introduction}

A credit contract implicitly means taking some risks by the contract parties. The credit risk (David D., 2009) can be defined by the loss suffered by an economic agent due to the failure in collecting the anticipated income flux in due time as a result of the deterioration of the credit quality of the debtor. In the present case, the commercial bank that granted credits in Swiss francs could suffer some losses if their clients were in the situation of not being able to pay. Another risk category associated to credit risk is the currency risk. The manifestation of the currency risk (Dedu V., Enciu A., 2001) affects the patrimony and the bank results according to 
the variations of the exchange rate. The measurement of the currency risk is performed via the exchange position. The banks are compelled to maintain a balance in what concerns the value of the exchange position by prudently managing the value of currency assets and debts. An important operator on the currency market is also the central bank. Currency sales and purchases performed (Cerna S., 2012) by the central bank aim, on the one hand, at stabilizing the rate of the national currency and, on the other hand, at building and managing the money reserve.

Taking risks that follow a credit contact must be an act acknowledged by both parties involved, both by the creditor and the debtor. When there are risks, solutions need to be found in order to minimise them.

Starting from this premise, the present paper will present some aspects regarding the influence of the Swiss Franc appreciation on the Romania banking system but also the reaction of other Central and Eastern European countries regarding this situation.

\section{Literature Review}

Switzerland's admission to the Monetary Economic Union determined the establishment a fixed exchange rate of 1.2 Euro/CHF. This happened because the capital and workforce movements in the Monetary Economic Union are free, the exchange rates are fixed and the monetary policy is unique. The causes that determined the Swiss National Bank to give up the aforementioned course were linked to the growth of nearly $90 \%$ of its assets in the GDP and the appreciation of the Swiss Franc exchange rate by 17\%-19\% compared to the main currencies (Euro, USD, GBP, JPY). In opinion of Cerna (2015), these phenomena show the limits of the enforcement of the monetary policy called "Quantitative Easing" (QE) by the main world central banks but also the fragility of the participation at the Monetary Economic Union of a country whose currency keeps its historical role of refuge currency. The quantitative easing involved the monetary policy interest rate until close to zero, even getting to printing money. It also had negative effects on financial markets, in fact only the international banks that benefitted from this money were saved from bankruptcy and moved on from the "too great to fall" phase to the "too great to fall but way too great to be saved" phase.

The fact that the Swiss Central Bank gave up the fixed rate of 1.2 euro/CHF on the $15^{\text {th }}$ of January 2015 had consequences on the countries in Central and Eastern Europe because a great part of the credits granted were in Swiss francs.

In all these countries, the national currencies were depreciated and the financial market rates were reduced but the impact on the debtors and the creditors was different. 
It is very clear that the decision of the Swiss Central Bank generated a state of anxiety among the countries in Central and Eastern Europe. However, despite the concerned reactions regarding stock markets, the region is much better prepared to face the alteration of the exchange rate than it was six years ago.

Exchange rate movements during the global financial crisis in 2007-2009 were unusual because many of the countries that were not at the centre of the crisis saw their currencies depreciate sharply. According to the Kohler (2010) two factors are likely to have contributed to these developments. First, during the latest crisis, safe haven effects went against the typical pattern of crisis-related flows. Second, interest rate differentials explain more of the crisis-related exchange rate movements in 2008-2009 than in the past. This probably reflects structural changes in the determinants of exchange rate dynamics such as the increased role of carry trade activity.

In what concerns Romania, the increase of the $\mathrm{CHF} / \mathrm{RON}$ rate was influenced by the appreciation of the EURO/CHF rate at the level from the $14^{\text {th }}$ of January 2015, considering the fact that the national currency is directly quoted to Euro, not Swiss francs. Hence, the intervention of the Romanian National Bank to maintain the rate from the $14^{\text {th }}$ of January 2015 resulted in: the fast and substantial diminishing of currency reserves and the fast arrest of exports, without being able to stop the tendency appreciation of the Swiss Franc compared to the RON. (Isarescu M., 2015).

The Swiss Franc appreciation did not endanger the stability of the financial system; however it created some problems for many Romanians, many of which have very low incomes. When such a situation emerges, it is normal that the politicians try to find fair solutions, which do not alter the general values of society.

In an interview for Radio France International on the $16^{\text {th }}$ of January 2015, Daniel Daianu stated that two principles help the shock created by the brutal appreciation of the Swiss franc: a.) sharing the load with the parties involved;

b.) restructuring the credits one way or another, especially since the interest rate is low internationally. It would be wise that those who granted the credits, those who received them, and even the state, share the load. (Daianu D., 2015).

Croitoru (2015) mentioned that a solution is fair if it does not generate moral hazard once applied. If many people happen to empathize with the victims, then the politicians are tempted to adopt solutions which can temporarily or partially sacrifice the profound values of society.

It is obvious that the decision of the SNB had major effects on the countries in the region, generating costs to those who were exposed to Swiss francs: banks, companies, natural persons. There is a series of questions that arise around this issue of the Swiss franc: Could the governments, the central banks or the ministry of finances have averted the acute financial crisis?; Why were currency credits 
granted in countries whose citizens have modest incomes and are paid in local currency?; Where was the risk analysis?; Is the financial education of the clients to blame? Besides these questions, finding solutions that support the affected persons is the most important thing. However, these solutions must be in concordance with the principles of the free market and the exercise of legal attributions in regard to the insurance of financial stability by the central banks.

\section{Research methodology}

The research to be performed starts from the following coordinates: the consequences of the Swiss franc appreciation on Central and Eastern European countries, the reaction of central banks in these countries regarding the situation created and finding realist solutions to diminish the negative effects, especially those on the non-financial clientele.

In order to reach the goals set concerning the approached theme, the study will be based on several methods of the scientific research: the comparison method, the observation method, the economic analysis method, the statistical method, the graphic method, the study case method, statistical analysis and comparative analysis. The methodological procedure aims at classifying the existent data, gathering and updating new data and also establishing new directions. The technique used is mainly based on Excel.

In order to gather historical data and information, the main method will be the observation method, both spontaneous and induced observation. This method will be applied to the research subject, mainly represented by the Romanian banking system, but also referring to other banking systems in Central and Eastern Europe, being useful to expose the situation generated by the Swiss franc appreciation in the area. The research will continue with the analysis of the impact of the Swiss franc appreciation on Central and Eastern European countries both on a macroeconomic and a microeconomic level. During the exposition, there will be a descriptive presentation based on statistic information, data and micro and macroeconomic indicators.

The case study is another method of performing a research and of emphasizing its results. It is an empirical research method that is oriented towards practice. Hence, a case study has been done regarding the evolution of a long-term credit in Swiss francs acquired by a Romanian natural person. The goal of this study is to emphasis the situation of people with average incomes, who were affected by the rise of the exchange rate for credits acquired in Swiss francs.

The research of the theme will be developed in two directions:

- doctrinarian - through works published by specialists in the field: presented in the references part; 
- normative - comparative - national and international statistic data bases, Eurostat, the International Monetary Fund, the National Commission for Prognosis, the National Statistics Institute, the Romanian National Bank, the Ministry of Public Finances, the European Central Bank.

The reports published by the Romanian National Bank: stability reports, annual reports, monthly articles, etc. the articles published at sessions of scientific communications will also be taken into consideration.

\section{Result and discussions}

4.1. The impact of the Swiss Franc appreciation on the banking system in Romania

At the beginning of the year 2008, 95\% of Romanians preferred currency credits according to a survey performed by the financial banking consultancy company, "Finzoom Romania", and among these, $11.5 \%$ borrowed Swiss francs, their number increasing at that time. According to the publication "The Money Channel 2008", financing in Swiss francs gained momentum due to promotional interest rates, because they were a few percentages lower than the Euro and much lesser interest rates than other currencies.

Loans in Swiss francs face greater risks than currencies such as the Euro and Dollar due to the fact that, in times of economic crisis, investors, in their attempt to protect themselves, invest in more secure assets, such as gold, exotic (less known) currencies or even raw materials and since the demand for these assets is rising, so does their price. This is what also happened to the Swiss Franc; as the demand for this currency rose, so did its price, and one of the consequences of this growth was the rise of monthly instalments for credits in this currency. The evolution of the Swiss franc in Romania is portrayed in the following chart:

Figure 1.The evolution of the Swiss franc in Romania

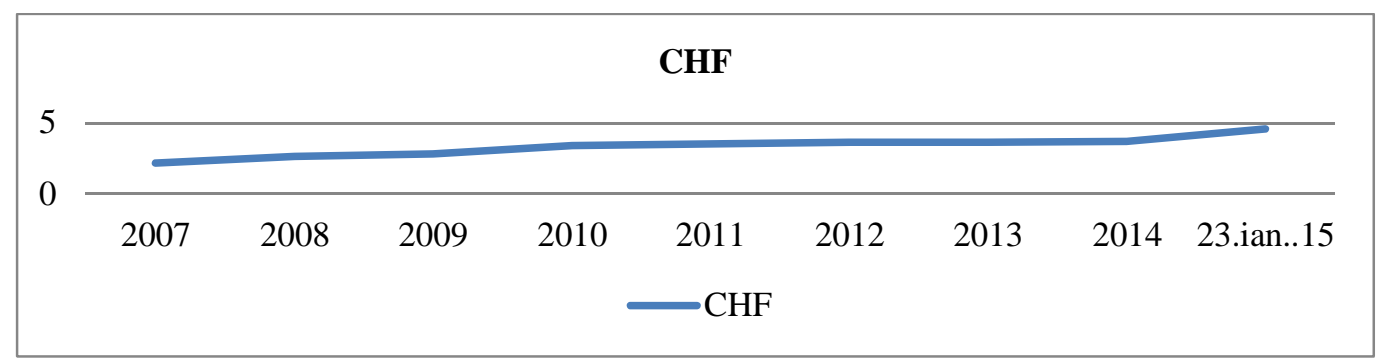

Source: Authors according to the CHF rate published on www.bnr.ro 
David, D., Rai, S.K., R., Paiusan, L. (2015)

Appreciation of the Swiss franc and its impact on Romania and other Central and Eastern European countries

After analyzing the evolution of the Swiss Franc compared to the RON, we can observe that the Swiss Franc significantly increased towards the end of the year 2007 when it was quoted at 2,55 RON. On the $23^{\text {rd }}$ of January 2015 the value of the Swiss Franc reaches 4,58 RON, registering a growth of over 100\% and in 2008, according to the RNB, the RON lost to the Swiss Franc over 21\%, which clearly influences the monthly installments of credits in this currency.

This growth of CHF/RON was caused by the appreciation of the Swiss Franc compared to the Euro, Dollar and other currencies as a result of the Swiss National bank renouncement at the minimum threshold of 1,2 EUR/CHF established on the $6^{\text {th }}$ of September 2011, thus a deployment of the currency in 2011-2014 can be observed.

Figure 2. The evolution of the CHF compared to the main currencies

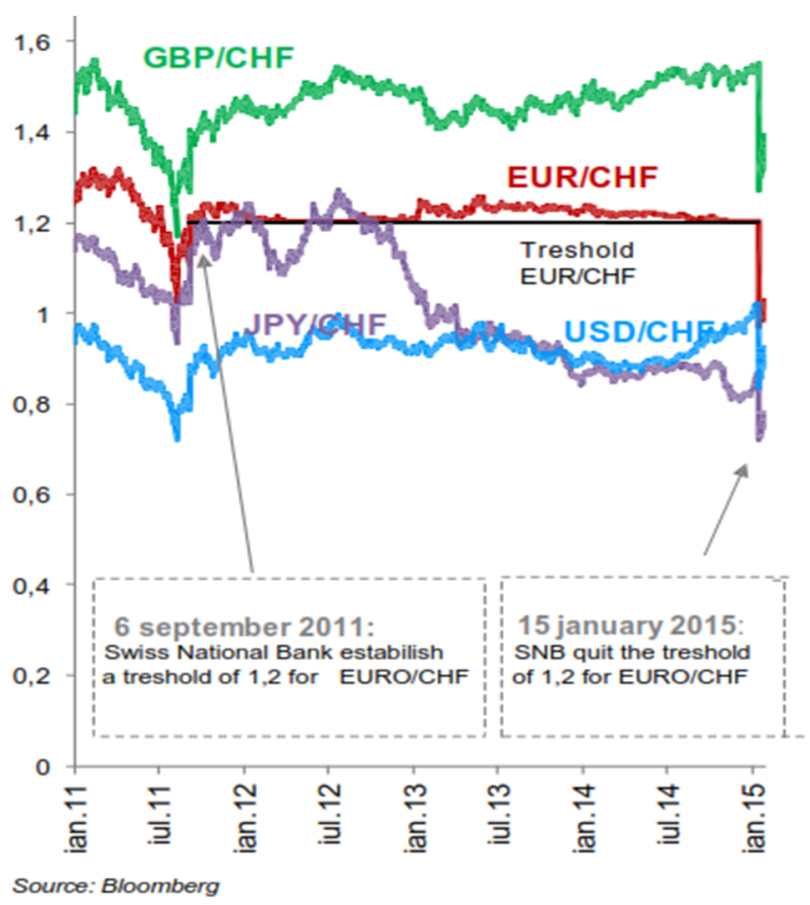

Natural and juridical persons who borrowed Swiss francs are at a disadvantage due to the great costs generated by the rate of buying and selling the Swiss currency.

As it results from the previously presented charts, the Swiss currency had a favorable evolution compared to Euro and RON. 
David, D., Rai, S.K., R., Paiusan, L. (2015)

Appreciation of the Swiss franc and its impact on Romania and other Central and Eastern European countries

Although the value of credits in Swiss francs did not represent a system risk for Romania, Romanian commercial banks sought to find solution to support their clients. In Romania, the value of Swiss Franc credits was estimated at 1,4\% of the GDP, as it result from the chart blow, five times less than Poland and seven times less than Hungary.

Figure 3. The value of credits in Swiss Franc

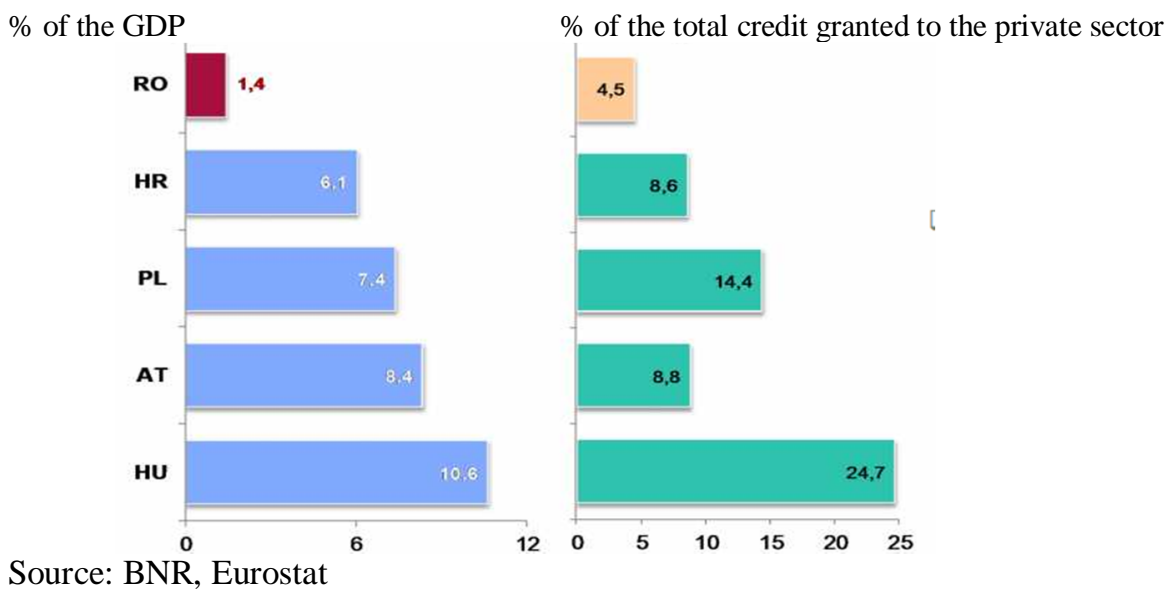

The number of natural persons with credits in CHF (75.412) represent $2.1 \%$ of the total number of debtors in this category. For comparison's sake, in Poland, the number of debtors in CHF is 500.000 (Isarescu M., 2015).

Figure 4.The structure of real estate credits granted to natural persons

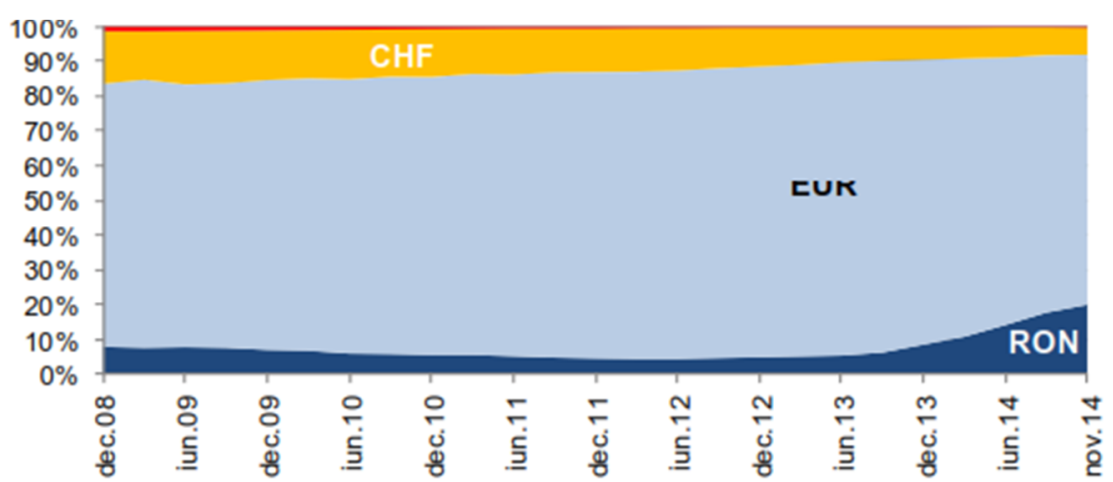

Source: BNR 
The reaction of Romanian banks regarding the support towards their clients was different. With the RNB agreement, they needed to find different solutions to the problem of Swiss Franc credits.

In the case of OTP Bank, after an analysis which focuses on the client's history and current conditions, the clients will be able to benefit from a temporary deduction of up to 1.5 percent of the margin of the interest rate for CHF credits with variable interest, for three months. OTP Bank Romania will be constantly analyzing the market evolution and assures its clients that it will continue to find measures of protection adapted to their real needs in order to support them in such unexpected situations (Popa D., 2015).

In order to come to their clients' aid, Volksbank Romania decided to maintain a fixed exchange rate of 3,20 RON for $1 \mathrm{CHF}$ (the VBRO exchange rate on the $31^{\text {st }}$ of December 2014) for three months (between the $20^{\text {th }}$ of January 2015 and the $17^{\text {th }}$ of April 2015) for the payment of the following three monthly installments owed by the clients. The rate offered by Volskbank Romania is $17,5 \%$ lower than the rate announced by the RNB on Monday, the $19^{\text {th }}$ of January 2015 - of 4,4716 RON/CHF, announced the bank officials. Practically, we perform the Franc credit conversion to the course from the day when this conversion was performed (according to the accounting law) and in order to get to that fixed rate, the bank grants a discount for which the shareholders pay from their own pockets. In technical terms, they increase the bank's capital (Popa D., 2015).

Raiffeisen Bank decreased the interest rate for clients with CHF credits, resetting it beforehand, five months ahead, according to the latest drop announced by the Swiss Central Bank, of 0,5\%. The bank was operating recalculations of the interest rate twice a year, the next one being scheduled for July. According to the announcement made by the bank officials, the recalculation of the interest rates came into operation on the $23^{\text {rd }}$ of January 2015. Raiffaisen Bank has a relatively narrow portfolio of clients exposed to $\mathrm{CHF}$, respectively 8.800 clients, and all the credits granted are vouched for with real estate. "Starting with the year 2009, the bank offers restructure solutions for clients with credits in CHF or EUR. Since 2012, Raiffeisen Bank also offers individualized solutions for clients with financial difficulties who want the conversion of CHF or EUR credits into RON" (Popa D., 2015).

Romanian Bank decided to lower the interest rate for clients with Swiss Franc credits (CHF) with over $0,8 \%$ by applying the LIBOR index on the $26^{\text {th }}$ of January 2015, thus absorbing a part of the negative impact generate by the recent depreciation of the national currency compared to the CHF. This discount was applied until the next scheduled update of interest rates based on the LIBOR index, according to current conditions (Popa D., 2015). 
David, D., Rai, S.K., R., Paiusan, L. (2015)

Appreciation of the Swiss franc and its impact on Romania and other Central and Eastern European countries

We must mention the fact that, in Romania, the creditors' situation does not represent a system risk. The net currency position expressed in Swiss francs was not a source of speculation for the banks, having a very low share in the total of inherent funds. Romanian banks have prudently managed the value of assets and debts in CHF.

Figure 5. The net currency position of credit institutions Percentage of the total of inherent funds of credit institutions

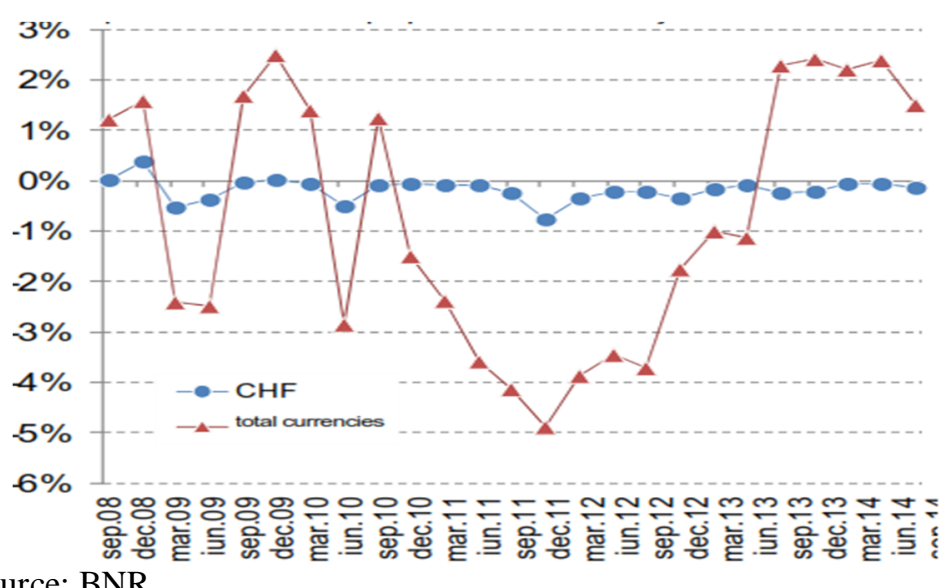

Source: BNR

Figure 6. Debtors' distribution in CHF according to the size of the credit

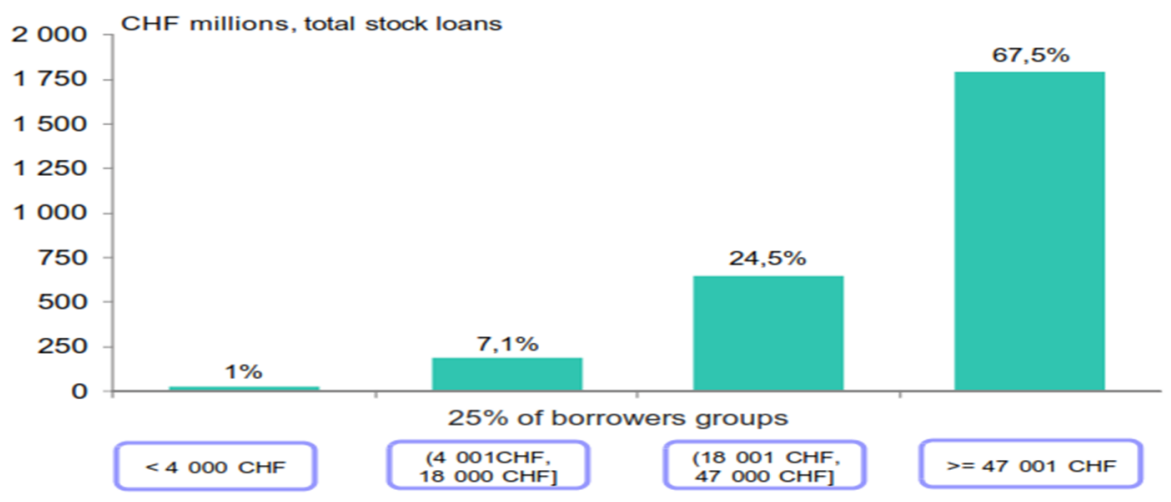

Source: CRC, BC,BNR calculations

Furthermore, at the Romanian banking system level, CHF credits are not homogenous as value. As it results in the chat below, $25 \%$ of the debtors hold $1 \%$ 
David, D., Rai, S.K., R., Paiusan, L. (2015)

Appreciation of the Swiss franc and its impact on Romania and other Central and Eastern European countries

of the credit stock (they have credits of under $4.000 \mathrm{CHF}$ ). Another $25 \%$ of debtors hold $67.5 \%$ of the credit stock (they have credits over $47.000 \mathrm{CHF}$ ).The situation of those who have credits lower than $4.000 \mathrm{CHF}$ cannot be compared to that of those with credits higher than 47.000 CHF.

Analyzing the debtors' average CHF debt degree, we can notice that those whose monthly average incomes are under $2500 \mathrm{RON}$ are presently over-indebted as a result of: the deterioration of incomes during the crisis and the appreciation of CHF. Debtors with incomes under 700 RON, who have a debt degree of $184 \%$ and debtors with incomes over $7000 \mathrm{RON}$, who have a debt degree of $26 \%$ cannot be treated similarly.

Figure 7. The debtors' average $\mathrm{CHF}$ debt degree according to the income category

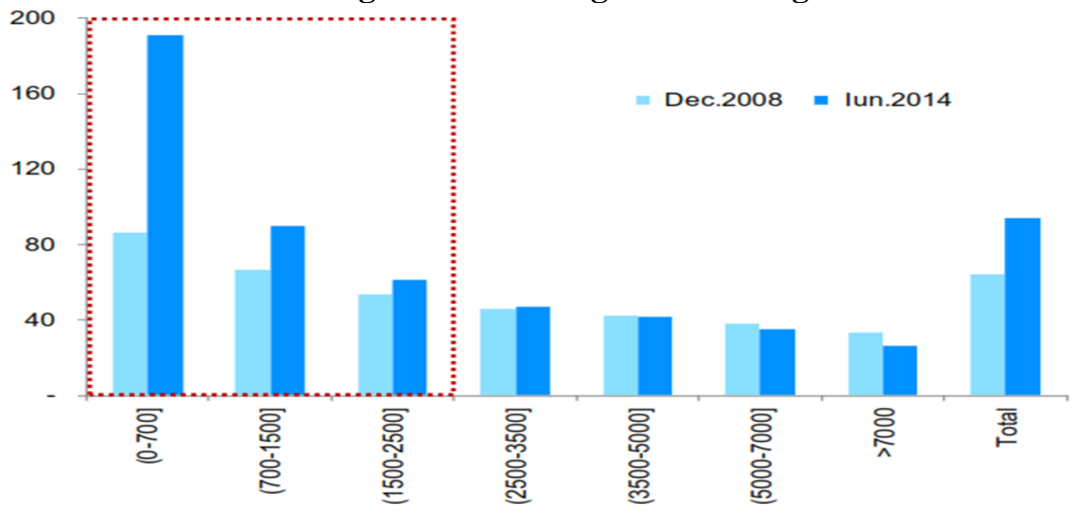

Source: CRC, BC, ANAF

Besides the credit risk, clients are also submitted to the interest rate risk, and the reference interest rate of the Swiss Franc also registered a rise during 2007 January 2015, thus getting to the delay of installments in the Swiss currency due to the high monthly installments.

Example:

In the case of a mortgage credit purchased in 2007 on a period of 26 years, at a rate of 2,17 RON/CHF, of 130.000 RON, with the CHF equivalent of $59.908 \mathrm{CHF}$ and an installment of 500 RON, with the CHF equivalent of $230 \mathrm{CHF}$, a monthly income of $2.500 \mathrm{RON}$, a family with two children could easily handle the credit so that they can still get by. The progressive appreciation of the Swiss currency since 2007 led to the rise of the monthly installment which, in December 2014 reached the value of $855 \mathrm{RON}$, with the Franc equivalent of $230 \mathrm{CHF}$.

We believe that in 2014, with an installment of $855 \mathrm{RON} /$ month and with the net income registered in 2007, the family could have got by and paid the installment in due time. However, considering that the net income of the family dropped at $1.500 \mathrm{RON} /$ month in 2014, they cannot handle the monthly installment and consumptions so that they can live decently, especially since the Swiss currency continued to rise in 2015 as well when in January, the $23^{\text {rd }}$, it registered a historical threshold of 4,58 
RON/CHF, which represent a growth of 23 percent compared to the end of 2014. This leads to the fact that the installment of $500 \mathrm{RON} / \mathrm{month}$ in 2007 reached $1.050 \mathrm{RON} / \mathrm{month}$ in 2015 , which is impossible to pay with a net income of $1.500 \mathrm{RON} / \mathrm{month}$.

As shown above, banks are under the necessity of finding solutions in order to support the people who really need it and of relying on a reasonable division of costs so as not to affect the stability of the Romanian financial-banking system.

In Romania, credits in CHF do not represent a system risk because they have a low share in the GDP and in the total of credits. Credits in CHF present a special variety: according to the level of income of the debtors, according to the destination of the credit, according to the volume of the credit.

In Romania, there are vulnerable social groups, which leads us to the conclusion that there is not only one general situation, but several different solutions.

\subsection{The impact of the appreciation of the Swiss franc on other countries in Central and Eastern Europe}

The issue of the Swiss Franc was also felt by other Central and Eastern European countries, however, their approach was different.

In Hungary, the issue was rather simply tackled. The government imposed the banks to absorb most of the currency shock by implementing a mechanism through which the citizens can reimburse credits at a fixed rate considerably lower than the one on the market. (256,6 forints per franc, in January of the current year its level being of 319,1 forints/CHF). Victor Orban, the Prime Minister of Hungary was harshly criticized for this measure, however, this was one of the favorite themes of his campaign which helped him take office and he eventually managed to enforce it (The Economist, 2015). The conversion rate was imposed by the Central Bank of Hungary at the market level at the time of the decision, in November 2014. The interest rate applied to converted credits was based on the interbank interest rate of the forint due in 3 months. The interest rate margin was maintained at the level of the risk bonus of the initial credit, but not higher than 5,5\% (subsequently amended to $4,5 \%$ ) for residential mortgage credits and, respectively, 7\% (subsequently amended to 6,5\%) for real estate guarantee credits. The Central Bank of Hungary committed to supplying commercial banks with 8 billion Euros in cash. This decision was influenced by the great share (50\%) of credits in CHF in the total of credits granted by local administrations, whose incapability to pay subsequent to the forint depreciation compared to the CHF would have substantially affected the state budget. Hungary is among the countries with the highest level concerning the share of CHF credit in the GDP and in the total of credits and loans denominated in CHF. 
Poland has by far the most affected economy on this side of Europe as a number of approximately 500.000 natural persons loaned Swiss francs. (Isarescu M., 2015) On the $28^{\text {th }}$ of January 2015, the Minister of Finances declared that supporting the debtors by converting credits denominated in francs to the local currency at a different rate than the daily rate is excluded because the accomplishment of this plan would affect the stability of the Polish banking system. Polish authorities recommended credit institutions to find solutions regarding lowering the interest rate for CHF in order to support the lowering of costs for debtors. The conversion of Swiss franc credits at a historical rate was not agreed by banks as they would have been negatively affected by the unsustainable rise of costs (Skolimowski P., Maciej O., 2015).

Croatia, another country affected by the issue of the Swiss franc constituted a law which froze the HRK/CHF rate for a year in order to reimburse credits denominated in CHF on the level before the appreciation of this currency. This measure was applied regardless of the type or volume of the credit and the rate differences were fully taken by the banks.

From the presented data, it results that the measures taken by the states of the countries affected by the appreciation of the Swiss franc were different compared to the particularities of Swiss franc credits. The fact that Romania took some of the aforementioned measure is considered inopportune because the context and associated costs are different.

\section{Conclusions}

The appreciation of the Swiss franc in relation to the main currencies (Euro, USD, GBP, JPY) had consequences on the Central and Eastern European countries because most of the credits granted were in Swiss francs. Although there were some reactions on the stock market, the region proved that it was better prepared to face the exchange rate alteration than it was six years ago.

The Central and Eastern European states intervened differently in order to balance the situation created taking into consideration the particularities characteristic to CHF credits. If in Romania and Poland the idea of converting the Swiss franc at a historical rate in concordance with the national currency for credits denominated in Swiss francs was not accepted, that is not what happened in Hungary and Croatia. In Hungary, all losses generated by the appreciation of CHF in the case of credits denominated in Swiss francs were transferred, given the fact that the National Bank of Hungary decided to supply the commercial banks with 8 billion Euro in cash. In Croatia, the exchange rate was frozen for a year at a value previous to the appreciation on the Swiss franc.

The solutions offered to fight the negative effects of the Swiss franc appreciation must consider the following principles: 
- They must be oriented towards the people who really need support (ex.: the drop of monthly incomes of vulnerable people in parallel with the rise of the reimbursement installment of the credit and interest rates in Swiss francs);

- They must not affect the financial stability of the banking system;

- They must not discriminate against debtors in other currencies (RON, Euro, dollars);

- They must not breach the Treaty concerning the European Union and the conditions of admission of member states, meaning the free circulation of capitals must not restricted.

In Romania, the political class speculated this moment and turned it into an electoral moment, soliciting the application of unrealistic solutions by the National Bank of Romania. Hereunder, we mention the intervention of the RNB to bring the RON/CHF rate at the level of the rate in the $14^{\text {th }}$ of January 2015 (namely 3,7 RON/CHF). Due to the fact that the RON/CHF rate is not directly quoted to Euro, it would have been necessary to appreciate the RON/Euro rate at 3,7, which would have been impossible to maintain on a long term and which would have had negative effects on the currency reserves but also on exports. We believe that another unrealistic solution is the conversion of credits denominated in CHF to RON, at different rate than the market rates on the day of the conversion. Applying this solution would affect the level of solvability of 2 to 4 banks which would have needed substantial capital infusions. The solvability rate would drop from $17 \%$ to $14 \%$ in the entire Romanian banking system.

In what concerns the Romanian banking system we believe that the following solutions would be appropriate to balance the situation created by the Swiss franc appreciation:

- The chart of credit rescheduling;

- The conversion of credits in RON at the daily rate or granting a discount concerning the debt service;

- The temporary reduction of the interest rate for credits in CHF in order to compensate the effect of the CHF appreciation. This solution is efficient taking into consideration the high degree of debt of the population, especially of debtors with gross monthly incomes of $3.000 \mathrm{RON}$.

Regardless of the solutions offered by the banks, the following elements must be taken into consideration: the principles of the free market, the support of the state for the vulnerable citizen groups and the enforcement of legal attributions concerning the insurance of financial stability by the commercial banks.

\section{References}

1. David D. (2009), Contabilitatea bancara a creditelor acordate clientelei nefinanciare, Editura Gutenberg Univers, Arad; 
David, D., Rai, S.K., R., Paiusan, L. (2015)

Appreciation of the Swiss franc and its impact on Romania and other Central and Eastern European countries

2. Daianu D. (2015), Marele impas in Europa. Ce poate face Romania?, Editura Polirom, Bucuresti;

3. Dedu V., Enciu A. (2001), Contabilitate bancara, Ed. Economica, Bucuresti;

4. Cerna S., Interventie in dezbatere, Conferinta de Drept bancar, Creditul bancar in moneda straina. Evolutii Economice, legislative si jurisprudentiale, Timisoara, 26-27 martie 2015;

5. Cerna S., Moneda si finante internationale (2012), Editura Universitatii de Vest, Timisoara;

6. Isarescu M., (2015), Problema creditelor in franci elvetieni, retrived from:http://www.hotnews.ro/stiri-esential-19239160-live-text-mugur-isarescuproblema-francilor-elvetieni.htm, Acccessed in february 2015;

7. Croitoru L., Problema francului si independenta BNR, retrieved from: http://www.hotnews.ro/stiri-opinii-19175981-problema-francului-independentabnr.htm, Accessed in march 2015;

8. Kohler M (2010), Exchange Rates During Financial Crises. BIS Quarterly Review, March 2010. Available at SSRN: http://ssrn.com/abstract=1561579;

9. Popa D. (2015), Scurta recapitulare a dosarului "francul elvetian", http://economie.hotnews.ro/stiri-finante_banci-19209638-scurta-recapitularedosarului-francul-elvetian-cum-reactionat-pana-acum-bancile-comerciale-bnrclasa-politica-avocatii-clientilor-dar-romanii-imprumutati-chf-vezi-text-cumprocedat-tarile-din-jur.htm,Accessed in february 2015;

10. Skolimowski P., Maciej O., (2015), Eastern European Currencies Dive as Swiss Loan Costs Hurt Banks, retrived from: http://www.bloomberg.com/news/ articles/2015-01-15/polish-banks-zloty-slump-as-swiss-franc-mortgages-getexpensive, Accessed in january 2015;

11. OECD (2014), Central European Country - Economic forecast summary, retrived from:http://www.oecd.org/economy/cee-economic-forecast-summary.htm, Accessed in january 2015;

12. Financial Stability Report 2014, retrived from http://www.bnr.ro/Publicatiiperiodice-204.aspx, Accessed in january 2015;

13. Eurostat (2014), retrived from http://ec.europa.eu/eurostat/statistics-explained/ index.php/Exchange_rates_and_interest_rates\#Main_tables;Accessed march 2015; 14. The Economist (2015), Currency risk, retrived from http://www.economist. com/news/europe/21639760-poles-were-slow-get-out-swiss-franc-mortgages-nowthey-are-paying-price-currency-risk, Accessed in march 2015;

15. http://finzoom.ro/articole; Probleme pentru cei cu credite in franci elvetieni, www.finzoom.ro/Info/art/.../ c3e416c5f6114a55abf1a3c10badb1cb/, Accesed in february 2015. 